TEACHING : Jurnal Inovasi Keguruan dan IImu Pendidikan

Vol. 1. No. 3 September 2021 e-ISSN : 2775-7188 | p-ISSN : 2775-717X

\title{
PENINGKATAN MINAT BELAJAR PENDIDIKAN AGAMA KRISTEN DENGAN MENGGUNAKAN METODE DISCOVERY LEARNING PADA MATERI HIDUP DALAM KESETIAAN KELAS X IPS SEMESTER GANJIL TAHUN PELAJARAN 2019/2020
}

\author{
ROSLINA PANJAITAN \\ SMA Negeri 2 Tanjung Selor \\ e-mail: barnabas.lina@gmail.co.id
}

\begin{abstract}
ABSTRAK
Penelitian ini bertujuan untuk mengetahui: Bagaimana minat belajar peserta didik SMA Negeri 2 Tanjung Selor Pada Mapel Agama Kristen dalam memahami, materi hidup dalam kesetiaan sebelum diterapkan Metode discovery learning. Dan bagaimana minat belajar peserta didik pada mapel Pendidikan Agama Kristen materi hidup dalam kesetiaan sesudah diterapkan Metode discovery learning. Apakah Metode discovery learning dapat meningkatkan minat belajar beserta didik pada mapel Pendidikan Agama Kristen materi hidup dalam kesetiaan sesudah diterapkan metode discovery learning. Penelitian ini merupakan penelitian tindakan kelas yang terdiri dari 2 (dua) siklus yang setiap siklus terdiri atas 4 (empat) tahapan. Siklus I dan II masing-masing terdiri dari 3 kali pertemuan. Data kemampuan peserta didik dalam memahami hidup dalam kesetiaan dikumpulkan dengan menggunakan lembar observasi, angket, wawancara dan dokumentasi. Hasil analisis menunjukkan bahwa penerapan Metode discovery learning dapat meningkatkan hasil belajar peserta didik kelas X IPS SMA Negeri 2 Tanjung Selor, memahami hidup dalam kesetiaan. Siklus I sebesar 70\% ke siklus II sebesar 93\% dengan ketuntasan klasikal. Hasil ini menunjukkan terjadinya peningkatan pemahaman peserta didik sebesar $30 \%$. Secara kualitatif kemampuan kuantitatif peserta didik dalam memaham kesetiaan meningkat dari kualifikasi sedang ke tinggi. Dengan demikian, Penerapan metode discovery learning dapat meningkatkan pemahaman peserta didik terhadap materi kesetiaan kelas X IPS SMA Negeri 2 Tanjung Selor Tahun Pelajaran 2019/2020.
\end{abstract}

Kata Kunci: Peningkatan Minat Belajar, Pembelajaran Discovery learning.

\section{PENDAHULUAN}

Dalam kegiatan proses pembelajaran, minat/motivasi merupakan aspek yang sangat penting, karena (a) motivasi (minat) memberi semangat terhadap seorang peserta didik dalam kegiatan-kegiatan belajarnya, (b) motivasi (minat) merupakan perbuatan pemilih dari tipe kegiatan-kegiatan dimana seseorang berkeinginan untuk melakukannya, dan (c) motivasi (minat) juga memberi petunjuk pada tingkah laku (Rusyan, dkk., 1989: 96-97).

Sardiman A. M. (1988:6) menjelaskan bahwa minat diartikan sebagai suatu kondisi yang terjadi apabila seseorang melihat ciri-ciri atau arti sementara situasi yang dihubungkan dengan keinginan-keinginan atau kebutuhankebutuhannya sendiri. Sedangkan menurut Pasaribu dan Simanjuntak (1983:52) mengartikan minat sebagai "suatu motif yang menyebabkan individu berhubungan secara aktif dengan sesuatu yang menariknya. Selanjutnya menurut Zakiah Daradjat, dkk. (1996:133), mengartikan minat adalah "kecenderungan jiwa yang tetap ke jurusan sesuatu hal yang berharga bagi orang.

Sardiman, (2011: 83) mengemukakan bahwa ciri-ciri seseorang yang memiliki minat (motivasi) tinggi yaitu berupa; (1) Tekun dalam menghadapi tugas (dapat bekerja terus menerus dalam waktu yang lama, tidak pernah berhenti sebelum selesai), (b) Ulet menghadapi kesulitan ridak (tidak lekas putus asa), (c) Menunjukkan minat terhadap bermacam-macam masalah, (d) Lebih senang bekerja mandiri, (e) Cepat bosan pada tugas-tugas yang rutin (hal-hal yang berifat mekanis, berulang-ulang begitu saja sehingga kurang kreatif), (f) Dapat mempertahankan pendapatnya (kalau sudah yankin akan sesuatu), (g) Tidak mudah melepaskan hal yang diyakini itu, dan (h) Senang mencari dan memecahkan maslah soal-soal. Minat belajar adalah aspek psikologis seseorang yang menampakkan diri dalam beberapa gejala seperti : gairah, semangat, 
keinginan, perasaan, suka melakukan proses tingkah laku melalui berbagai kegiatan yang meliputi mencari pengetahuan dan pengalaman. Dengan kata lain minat belajar itu adalah perhatian, rasa suka, ketertarikan seseorang terhadap proses belajar yang dijalaninya dan kemudian ditunjukkan melalui keantusiasan partisipasi dan keaktifan dalam mengikuti proses yang ada.

Suatu kegiatan yang dilakukan tidak sesuai dengan minat akan menghasilkan prestasi yang kurang menyenangkan. Dapat dikatakan bahwa dengan terpenuhinya minat seseorang akan mendapatkan kesenangan atau kepuasan batin yang dapat menimbulkan motivasi. minat belajar adalah .kecenderungan dan kegairahan yang tinggi atau keinginan yang besar terhadap sesuatu (Muhibbin Syah, $2001: 136$ ).

Ahmad D. Marimba (1980:79) "Minat belajar adalah .kecenderungan jiwa kepada sesuatu, karena kita merasa ada kepentingan dengan sesuatu itu, pada umumnya disertai dengan perasaan senang akan sesuatu itu. Menegaskan pendapat tersebut, Mahfudh Shalahuddin mengemukakan bahwa minat belajar adalah perhatian yang mengandung unsur-unsur perasaan. Dengan demikian minat belajar, sangat menentukan sikap yang menyebabkan seseorang aktif dalam suatu pekerjaan, atau dengan kata lain, minat belajar dapat menjadi sebab dari suatu kegiatan (1990: 95).

Dari kelima pengertian tersebut dapat diambil kesimpulan bahwa minat belajar akan timbul apabila mendapatkan rangsangan dari luar. Dan kecenderungan untuk merasa tertarik pada suatu bidang bersifat menetap dan merasakan perasaan yang senang apabila ia terlibat aktif didalamnya. Perasaan senang ini timbul dari lingkungan atau berasal dari objek yang menarik.

Dengan demikian minat belajar merupakan faktor yang sangatlah penting dalam keberhasilan belajar peserta didik. Minat belajar peserta didik dalam mengikuti pembelajaran merupakan sesuatu yang penting dalam kelancaran proses belajar mengajar. Peserta didik yang mempunyai minat belajar tinggi dalam proses pembelajaran dapat menunjang proses belajar mengajar untuk semakin baik,. Minat adalah "Kecenderungan hati yang tinggi terhadap sesuatu". Minat merupakan sifat yang relatif menetap pada diri seseorang. Minat adalah ketertarikan atau kecenderungan yang tetap untuk memperhatikan atau terlibat terhadap sesuatu hal karena menyadari pentingnya hal tersebut. Sehubungan dengan hal itu, dalam proses pembelajaran Pendidikan Agama Kristen di SMA Negeri 2 Tanjung Selor, khususnya dalam materi pelajaran hidup dalam kesetiaan masih kurang. Hal ini dapat dilihat dari hasil evaluasi pembelajaran pada mata pelajaran tersebut seperti tampak pada Tabel 1

Tabel 1.Kualifikasi pencapaian belajar siswa

\begin{tabular}{|c|c|c|c|}
\hline Rentang Data & Kualifikasi & Jumlah & Persentase \\
\hline $90-100$ & Sangat Minat & 0 & $0 \%$ \\
\hline $80-89$ & Minat & 6 & $22,22 \%$ \\
\hline $70-79$ & Cukup Minat & 3 & $18,53 \%$ \\
\hline $69-50$ & Kurang Minat & 16 & $59,25 \%$ \\
\hline & & & \\
\hline
\end{tabular}

Sumber: Data nilai Harian Siswa, 2012

Berdasarkan Tabel 1 tersebut, tampak bahwa perolehan nilai peserta didik yang kurang dari 69 tergolong sangat rendah yaitu sebesar 59,25\%, nilai $60-69$ tergolong kurang minat. Nilai 70 - 79 tergolong cukup sebesar $18,53 \%$, yang memperoleh nilai lebih dari 80 tergolong tinggi, tergolong minatnya tinggi yaitu sebanyak 22,22\%. Dengan demikian dapat disimpulkan bahwa sebagian besar ketercapaian Kriteria Ketuntasan Materi (KKM) peserta didik kelas X IPS dalam materi hidup dalam kesetiaan pelajaran Pendidikan Agama Kristen relatif masih rendah. Hal ini terjadi dikarenakan terdapat beberapa kendala, antara lain minat belajar mengikuti pembelajaran yang masih kurang, serta faktor lingkungan yang kurang mendukung. Selain itu lebih dari 50\% peserta didik menunjukkan minat belajar yang rendah. 
Minat belajar yang rendah berdampak pada hasil belajar peserta didik yang hanya tuntas $33,33 \%$ saja, sehingga 66,67\% peserta didik belum tuntas dalam pembelajarannya. Sedangakan KKM pada mata pelajaran Agama Kristen adalah nilai $\geq 70$.

Untuk itu diperlukan adanya strategi melalui Metode Discovery Learning. Discovery learning adalah model mengajar yang dilaksanakan oleh guru dengan cara mengatur proses belajar dengan sedemikian rupa sehingga siswa mendapatkan pengetahuan yang sebelumnya belum diketahui dan sebelumnya dengan cara tidak disampaikan terlebih dahulu akan tetapi siswa menemukannya secara mandiri (Daryanto dan Karim, 2017). Model pembelajaran memiliki andil yang cukup besar dalam kegiatan belajar mengajar. Kemampuan menangkap pelajaran oleh peserta didik dapat dipengaruhi dari pemilihan model pembelajaran yang tepat, sehingga tujuan pembelajaran yang ditetapkan akan tercapai. Terdapat berbagai macam model pembelajaran yang dapat dijadikan alternatif bagi guru untuk menjadikan kegiatan pembelajaran di kelas berlangsung efektif dan optimal. Salah satu model pembelajaran yang dapat melibatkan atau mengaktifkan peserta didik dalam belajar adalah metode discovery learning. Metode discovery learning diartikan sebagai suatu prosedur mengajar yang mementingkan pengajaran, perseorangan, manipulasi objek dan lain-lain percobaan, sebelum sampai pada generalisasi. Sebelum peserta didik sadar akan pengertian, guru tidak menjelaskan dengan kata-kata. Penggunaan metode discovery learning dalam proses belajar mengajar, memperkenankan peserta didiknya menemukan sendiri informasi yang secara tradisional biasa diberitahukan atau diceramahkan saja.

Dari latar belakang itulah mengapa guru berperan sebagai peneliti hendak melakukan kajian lebih mendalam dalam sebuah Penelitian Tindakan Kelas (PTK) yang berjudul "Peningkatan Minat Belajar Pendidikan Agama Kristen menggunakan Metode Discovery Learning Pada Materi Hidup dalam kesetiaan kelas X IPS Semester Ganjil SMA Negeri 2 Tanjung Selor Tahun Pelajaran 2019/2020"

\section{METODE PENELITIAN}

Prosedur penelitian yang digunakan dalam penelitian ini adalah penelitian tindakan kelas. Rancangan yang digunakan adalah model rancangan yang diadaptasi Stephen Kemmis dan Mc. Taggart (1998) dengan menggunakan dua siklus, dengan masing-masing siklus terdiri dari empat tahapan yaitu: (1) Perencanaan, (2) Tindakan, (3) Observasi dan Evaluasi, dan (4) Refleksi.

Berikut ini adalah gambar rancangan penelitian tindakan kelas menurut Stephen Kemmis dan Mc. Taggart (1998) terlihat pada gambar 1 di bawah ini.

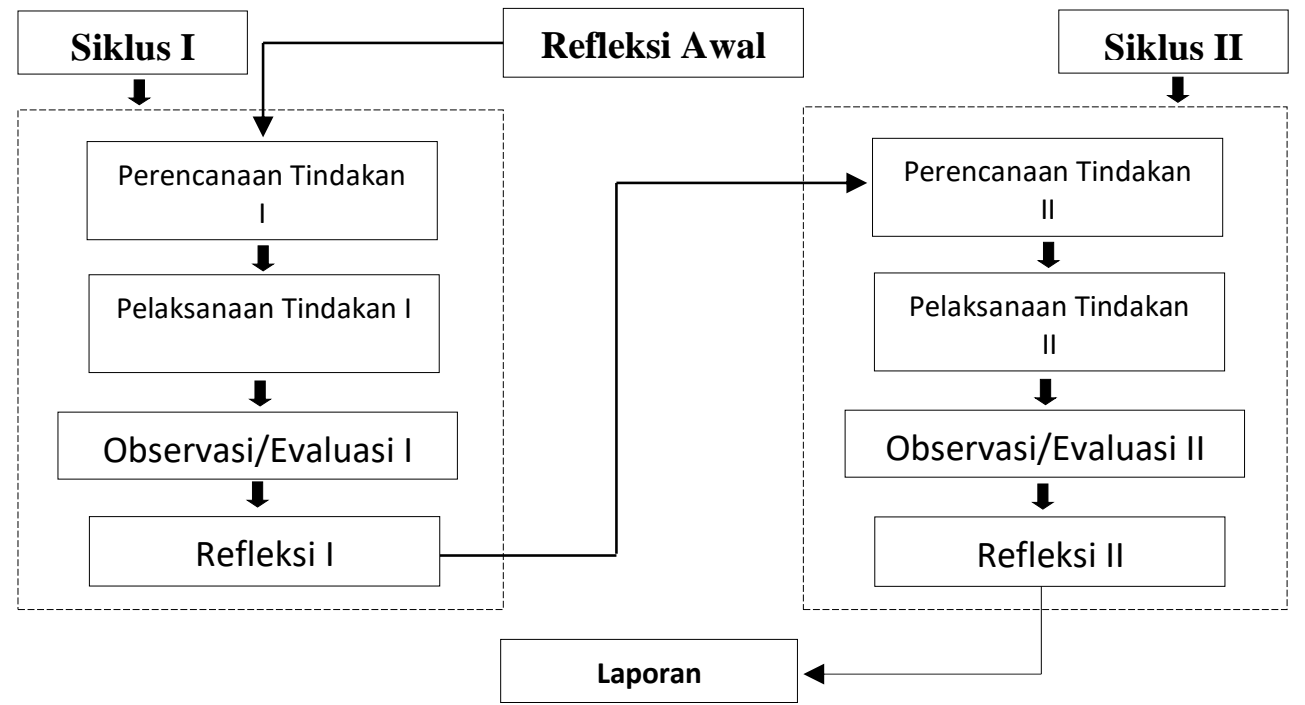

Gambar 1. Rancangan penelitian tindakan kelas

Pada siklus pertama sesuai dengan skema yang telah ditetapkan dilakukan beberapa tahapan: Tahap Pertama; Perencanaan. Pada tahap ini peneliti membuat RPP, berkonsultasi 
dengan teman sejawat membuat instrumen. Pada tahap menyusun rancangan diupayakan ada kesepakatan antara guru dan teman sejawat. Rancangan dilakukan bersama antara peneliti yang akan melakukan tindakan dengan guru lain yang akan mengamati proses jalannya tindakan. Hal tersebut untuk mengurangi unsur subjektivitas pengamat serta mutu kecermatan pengamatan yang dilakukan. Tahap Kedua, Tahap Pelaksanaan. Tindakan dilakukan dengan pembelajaran di kelas. Pada tahap ini peneliti giat melakukan tindakan menggunakan metode discovery learning dengan bantuan alat peraga. Rancangan tindakan tersebut sebelumnya telah dilatih untuk dapat diterapkan di dalam kelas sesuai dengan skenarionya. Tahap Ketiga, Pengamatan. Pengamatan dilakukan pada waktu tindakan sedang berjalan, keduanya berlangsung dalam waktu yang sama. Pada tahap ini, guru yang bertindak sebagai peneliti melakukan pengamatan dan mencatat semua hal yang diperlukan dan terjadi selama pelaksanaan tindakan berlangsung. Pengumpulan data ini dilakukan dengan menggunakan belajar yang telah tersusun, termasuk juga pengamatan serta dampaknya terhadap proses dan hasil belajar peserta didik. Tahap Keempat, Kajian. Tahapan ini dimaksudkan untuk mengkaji secara menyeluruh tindakan yang telah dilakukan, berdasarkan data yang telah terkumpul, kemudian dilakukan evaluasi guna menyempurnakan tindakan berikutnya. Refleksi dalam PTK mencakup analisis, penilaian terhadap hasil pengamatan atas tindakan yang dilakukan. Jika terdapat masalah dari proses refleksi maka dilakukan proses pengkajian ulang melalui siklus berikutnya yang meliputi kegiatan: perencanaan ulang, tindakan ulang, dan pengamatan ulang shingga permasalahan dapat teratasi.

Pada pelaksanaan siklus kedua (siklus II) proses pembelajaran yang dilakukan pada siklus ini meliputi : tahap (1) membuat RPP, berkonsultasi dengan teman sejawat membuat instrumen penilaian. Pada tahap menyusun rancangan yang dibuat berdasarkan hasil perbaikan dari kelemahan pada siklus 1, tahap (2) melakukan tindakan berupa dilakukan dengan pembelajaran di kelas. Pada tahap ini guru peneliti melakukan tindakan menggunakan metode discovery learning dibantu alat peraga, (3) melakukan pengamatan yang meliputi mengobservasi aktivitas belajar peserta didik selama proses pembelajaran, mengevaluasi proses pembelajaran. Tahap (4) melakukan refleksi tentang hasil aktivitas belajar peserta didik selama proses pembelajaran dan post tes (tes hasil belajar) pada akhir siklus.

\section{HASIL DAN PEMBAHASAN}

\section{a. Hasil Penelitian}

\section{Siklus 1, Pertemuan Pertama}

Pelaksanaan siklus I dilaksanakan pada hari Rabu 11 September 2019. Guru masuk kelas pukul 07.30 Wita bersama observer. Kegiatan pembelajaran diawali dengan mengucapkan salam dan meminta salah seorang siswa untuk memimpin doa serta mengecek kehadiran siswa. Setelah itu guru menyampaikan materi yang akan disampaikan dengan memberikan apersepsi tentang materi hidup dalam kesetiaan dengan menampilkan gambargambar tokoh Alkitab yang setia mempertahankan imannya untuk memotivasi peserta didik dan menjelaskan tujuan serta indikator dari pembelajaran tersebut dengan menuliskan di papan tulis. Kemudian kegiatan inti berlangsung selama 90 menit. Dalam kegiatan ini, guru menjelaskan mengenai pengertian hidup dalam kesetiaan sebagai materi awal. Setelah itu guru melakukan apersepsi terhadap peserta didik dengan mengajukan pertanyaan mengenai tokoh-tokoh pribadi setia dalam Alkitab yang diketahui peserta didik, dan guru memberi tanggapan terhadap jawaban peserta didik. Pada kegiatan penutup, guru bersama peserta didik menyimpulkan hasil pembelajaran. Kemudian guru menyampaikan materi untuk pertemuan selanjutnya dan mengingatkan kembali kepada peserta didik untuk mempelajari materi yang telah dipelajari. Diakhir pembelajaran guru meminta salah seorang peserta didik untuk memimpin doa penutup dan mengucapkan salam.

\section{Siklus I Pertemuan Kedua}


Pelaksanaan kedua dilaksanakan pada hari Rabu, 9 Oktober 2019. Guru melakukan pendahuluan dengan memberi salam dan mengecek keadaan peserta didik. Kemudian guru memberikan apersepsi mengenai pembelajaran sebelumnya yang bertujuan untuk mengembalikan ingatan siswa dengan mengajukan beberapa pertanyaan seperti apa itu kesetiaan? dan sebagian peserta didik dengan antusias menanggapi pertanyaan tersebut. Guru kemudian menjelaskan kembali secara rinci mengenai kesetiaan dan tokoh-tokoh Alkitab yang setia. Pada kegiatan inti berlangsung selama 90 menit dengan melakukan pendekatan diskusi. Pada siklus I pertemuan kedua guru menjelaskan materi mengenai jenis kesetiaan yang dibagi menjadi 2 , yaitu kesetiaan kepada Tuhan dan kesetiaan kepada sesama manusia. Sebelum pembelajaran berakhir diadakan post test untuk mengukur pemahaman peserta didik terhadap materi yang telah dijelaskan. Berdasarkan hasil pengamatan/observasi dan hasil tes selama proses pembelajaran Siklus I dapat dilihat pada Tabel 2.

Tabel 2. Distribusi Nilai Hasil Belajar peserta didik Pada Siklus 1

\begin{tabular}{|c|l|c|}
\hline No. & \multicolumn{1}{|c|}{ Uraian } & Hasil Siklus 1 \\
\hline 1. & Nilai Tertinggi & 90 \\
2. & Nilai Terendah & 50 \\
3. & Nilai rata-rata tes hasil belajar & 75,5 \\
4. & Jumlah peserta didik yang tuntas belajar & 10,00 \\
5. & Jumlah peserta didik yang tidak tuntas & 15,00 \\
6. & Persentase ketuntasan belajar & $33,33 \%$ \\
\hline
\end{tabular}

Berdasarkan pada tabel 1 di atas, dapat diketahui bahwa hasil belajar peserta didik kelas $X$. yang mengikuti pembelajaran dengan penerapan metode discovery learning diperoleh nilai rata-rata hasil belajar Pendidikan Agama Kristen sebesar 66,6 dan ketuntasan belajar 33,3\% atau ada 10 peserta didik dari 25 peserta didik sudah tuntas belajar. Hasil ini menunjukkan bahwa secara klasikal peserta didik belum tuntas belajar, karena peserta didik yang memperoleh nilai $\geq 70(\mathrm{KKM})$ hanya sebesar $33,3 \%$ lebih kecil dari prosentase ketuntasan yang dikehendaki yaitu sebesar $80 \%$.

Berdasarkan hasil refleksi siklus pertama (siklus I) diketahui bahwa tidak tercapainya ketuntasan aktivitas belajar peserta didik dipengaruhi oleh beberapa hal yaitu: 1) anak belum terbiasa dalam melaksanakan metode pembelajaran, 2) masih terdapat peserta didik yang pasif mengikuti pembelajaran seperti kurangnya minat peserta didik untuk bertanya dan menjawab pertanyaan guru. Oleh karena itu peneliti merasa perlu melakukan perbaikan tindakan terhadap proses pembelajaran yang telah dilakukan pada siklus pertama (siklus I) dengan lebih mendekatkan diri kepada peserta didik, guru memberikan contoh kesetiaan kepada siswa yang merasa kesulitan dalam melakukan, di samping itu guru membantu peserta didik secara intensif terutama peserta didik yang pasif.

\section{Siklus II Pertemuan Pertama}

Siklus ini dilaksanakan pada hari Senin, 9 Oktober 2019. Pada siklus ini kegiatan pembelajaran hampir sama dengan siklus pembelajaran sebelumnya dan menindaklanjuti kekurangan-kekurangan yang terdapat pada siklus sebelumnya. Pada pertemuan pertama siklus ini, model pembelajaran yang diterapkan mengacu pada RPP yang telah disusun, yakni menerapkan Metode Discovery Learning . Kegiatan inti berlangsung selama 90 menit dengan membentuk kelompok dan menayangkan video tokoh Alkitab tentang kesetiaan yaitu Abraham. Sebelum video ditayangkan guru menjelaskan sedikit tentang latar belakang tokoh Abraham baik dari imannya, dan kehidupannya dalam menantikan janji Tuhan agar peserta didik bisa memahami materi yang akan ditonton. Setelah menonton dan mengamati video tersebut, masing-masing kelompok diharapkan dapat mempersentasikannya di depan kelas. Pada akhir kegiatan pembelajaran, guru kembali memberikan tanggapan berupa reward maupun perbaikan-perbaikan yang ditujukan kepada peserta didik, serta memberikan penguatan. Post test diberikan 15 menit sebelum kegiatan pembelajaran 
berakhir guna mengukur pemahaman peserta didik terhadap materi yang telah diberikan. Setelah dilakukan tindakan berupa pembelajaran di siklus kedua maka diperoleh hasil observasi aktivitas dan hasil belajar pada siklus kedua seperti terlihat dalam tabel 2.

Tabel 2. Distribusi Nilai Hasil Belajar peserta didik Pada Siklus 2

\begin{tabular}{|c|l|c|}
\hline No. & \multicolumn{1}{|c|}{ Uraian } & Hasil Siklus 2 \\
\hline 1. & Nilai Tertinggi & 100 \\
2. & Nilai Terendah & 75 \\
3. & Nilai rata-rata tes hasil belajar & 81,12 \\
4. & Jumlah peserta didik yang tuntas belajar & 25,00 \\
5. & Jumlah peserta didik yang tidak tuntas & 00.00 \\
6. & Persentase ketuntasan belajar & $93 \%$ \\
\hline
\end{tabular}

Berdasarkan pada tabel 2 di atas, dapat diketahui bahwa hasil belajar peserta didik kelas X yang mengikuti pembelajaran dengan penerapan Metode Discovery Learning diperoleh nilai rata-rata hasil belajar Pendidikan Agama Kristen sebesar 81,12 dan ketuntasan belajar $93 \%$ atau ada 25 peserta didik dari 25 peserta didik sudah tuntas belajar. Hasil ini menunjukkan bahwa secara klasikal peserta didik sudah tuntas belajar, dan sudah memenuhi syarat karena jumlah peserta didik yang telah mencapai nilai $(\mathrm{kkm}) \geq 70$ sebanyak 93\% dan berada diatas kriteria ketuntasan klasikal 81,12 maka penelitian ini berakhir di siklus kedua 2. Perbandingan hasil belajar peserta didik pada sikus 1 dengan siklus 2 ditunjukkan pada tabel berikut ini.

Tabel. 3 Perbandingan hasil belajar peserta didik pada siklus 1 dan siklus 2

\begin{tabular}{|c|l|c|c|}
\hline No. & \multicolumn{1}{|c|}{ Uraian } & Hasil Siklus 1 & Hasil Siklus 2 \\
\hline 1. & Nilai Tertinggi & 90 & 100 \\
2. & Nilai Terendah & 50 & 75 \\
3. & Nilai rata-rata tes hasil belajar & 66,06 & 81,12 \\
4. & Jumlah peserta didik yang tuntas & 10,00 & 25,00 \\
5. & Jumlah peserta didik yang tidak tuntas & 15.00 & 00.00 \\
6. & Persentase ketuntasan belajar & $45 \%$ & $93 \%$ \\
\hline
\end{tabular}

Berdasarkan pada tabel 3 di atas, dapat diketahui bahwa hasil belajar peserta didik kelas X IPS yang mengikuti pembelajaran dengan penerapan Metode Discovery Learning mengalami peningkatan dari siklus I ke Siklus 2 sebesar 15,05\% dari rata-rata 66,06 pada siklus I menjadi 81,12 pada siklus II. Sedangkan ketuntasan klasikal mengalami peningkatan sebesar $48 \%$ dari KK $45 \%$ menjadi KK 93\% pada siklus II.

\section{b. Pembahasan}

Pada siklus I diperoleh hasil minat belajar peserta didik dengan nilai rata-rata kategori minat sebesar 80-90 sebanyak 6 peserta didik dari jumlah keseluruhan 25, pada kategori cukup peserta didik sebanyak 3 orang dengan nilai rata-rata 70-79, pada kategori kurang minat berjumlah 16 pesrta didik dengan nilai rata-rata 69-50, Sedangkan ketuntasan hasil belajar peserta didik sebanyak 15 peserta didik dari jumlah yang dikategorikan tidak tuntas. Jumlah peserta didik dari keseluruhan dikategorikan tuntas sebanyak 10 peserta didik. Dari hasil ini dapat dinyatakan bahwa ketuntasan belajar peserta didik secara maksimal belum tercapai. Hal ini disebabkan sebagian peserta didik masih kurang keaktifannya dalam memberikan perhatian pada saat pembelajaran, demikian juga peserta didik yang mengajukan pertanyaan dan tanggapan yang masih sangat kurang, dan ada peserta didik yang kurang mampu untuk menyimpulkan pelajaran.

Pada siklus II diperoleh hasil belajar dengan nilai rata-rata sebesar 81,12 dan nilai yang diperoleh berada pada kategori sangat minat sebesar 22,22\% dengan jumlah peserta didik 6 dari 
jumlah keseluruhan. Pada kategori minat sebesar 59,25\% dengan jumlah peserta didik sebanyak 16 dari jumlah peserta didik secara keseluruhan. Pada kategori cukup sebesar 18,53\% dengan jumlah peserta didik 3. Sedangkan ketuntasan hasil belajar peserta didik diperoleh 100\% dengan jumlah 25 dari jumlah keseluruhan. Dari hasil ini dapat dinyatakan bahwa ketuntasan belajar peserta didik secara klasikal sudah tercapai karena menurut ketentuan Depdiknas dan disesuaikan di sekolah SMA Negeri 2 Tanjung Selor bahwa peserta didik dikatakan tuntas belajar jika memperoleh skor minimal 70 dari skor ideal, dan tuntas secara klasikal apabila 80\% dari jumlah peserta didik yang telah tuntas belajar sehingga penelitian tidak dilanjutkan lagi pada siklus berikutnya.

Hal ini sesuai dengan hasil meta analisis metode pembelajaran yang dilakukan oleh Soedomo,1990 (dalam Puger, 2004) yang menyatakan bahwa metode pembelajaran yang diterapkan oleh seorang guru berpengaruh terhadap hasil belajarnya. Dengan demikian dapat dikatakan penerapan metode pembelajaran Discovery Learning dapat meningkatkan hasil belajar dan pemahaman peserta didik tentang hidup dalam kesetiaan di kelas. Pembelajaran Discovery Learning sangat membantu guru meningkatkan kualitas pembelajaran di kelas terutama dalam mengajarkan materi memahami hidup dalam kesetiaan maupun materi lainnya.

\section{KESIMPULAN}

Dari hasil penelitian dan pembahasan, maka dapat dikemukakan bahwa setelah dilakukan penelitian tindakan kelas dengan menggunakan metode pembelajaran Discovery Learning pada peserta didik kelas X IPS di SMA Negeri 2 Tanjung Selor semester ganjil tahun pelajaran 2019/2020 terjadi perubahan penguasaan materi hidup dalam kesetiaan. Perubahan ini nampak pada hasil observasi maupun pos test yang didapat dari tindakan. Tindakan pada siklus I, dan tindakan dari siklus II. Data perkembangan hasil peningkatan belajar peserta didik dapat dilihat dari rata-rata perolehan nilai peserta didik pada masing-masing siklus mengalami peningkatan yakni pada siklus 1 rata-rata hasil belajar 66,06 menjadi 81,12 pada siklus 2 . Persentase ketuntasan belajar juga mengalami peningkatan dari $45 \%$ pada siklus 1 menjadi $93 \%$ pada siklus 2. Dengan hasil penelitian ini, penulis menyarankan kiranya rekan-rekan guru dapat mencoba menerapkan metode pembelajaran Discovery Learning untuk materi yang lain.

\section{DAFTAR PUSTAKA}

A.M. Sardiman. (2011). Interaksi dan Motivasi Belajar Mengajar. Jakarta: Rajawali Press. Darajat, Zaskiah. (1996). Ilmu Jiwa Agama. Jakarta: Bulan Bintang.

Dalyono. (2009). Psikologi Pendidikan. Jakarta: Rineka Cipta.

I.L. Pasaribu, B. Simanjuntak. (1983). Proses Belajar Menjagar. Bandun, Transito

Kemmis, S., \& McTaggart, R. (1997). The Action Research Planner. Geelong: Deakin University.

Karim Syaiful, Daryanto. (2017). Pembelajaran Abad 21. Yogyakarta: Gravo Media.

Marimba, Ahmad D. (1980). Pengantar Filsafat Pendidikan Islam. Bandung: PT. Al-Ma'arif.

Muhibbin, Syah. (2008). Psikologi Pendidikan dengan Pendekatan Baru. Bandung: Remaja Karya.

Rusyan, dkk. (1989). Pendekatan Dalam Proses Belajar Mengajar. Bandung, Remaja Karya. Salahudin, Mahfudh. (2006). Strategi Belajar. Surabaya : Bina Ilmu. 